\title{
Rat skin physiology is modified by age
}

\section{A Fisiologia da pele de rato é modificada pela idade}

\author{
Graziela Sponchiado $^{1-4}$, C Mello-Sampayo ${ }^{1,4}$, Maria M Pereira ${ }^{2}$, Henrique Silva $^{2,4}$, MF Otuki ${ }^{3,5}$, \\ B Silva-Lima $^{1,4}$ \& Luis Monteiro Rodrigues ${ }^{2,4}$ \\ ${ }^{1}$ iMed Research Institute for Medicines and Pharmaceutical Sciences, Universidade de Lisboa - Fac Pharmacy, \\ Lisbon, Portugal. \\ ${ }^{2}$ CBIOS - Universidade Lusófona's Research Center for Health Science and Technologies, \\ Campo Grande, 376, 1749-024, Lisboa, Portugal \\ ${ }^{3}$ Programa de Pós-Graduação em Ciências Farmacêuticas, Universidade Federal do Paraná (UFPR), Curitiba, \\ PR, Brasil. Bolsista da CAPES- Proc. n 9878/11-4. \\ ${ }^{4}$ Pharm.Sc Department, Universidade de Lisboa - Fac Pharmacy, Lisboa, Portugal. \\ ${ }^{5}$ Department of Pharmaceutical Sciences, State University of Ponta Grossa (UEPG), Ponta Grossa, PR, Brazil. \\ Email: graziela_s@hotmail.com
}

\begin{abstract}
Animal models have been useful in the study of specific mechanisms affecting human skin. Such is the case with ageing and the micromechanical changes determining wrinkles in UV- irradiated mice. These models enabled us to understand that ageing encompasses many peculiar mechanical responses which cannot be explained by homogeneous deformation of the skin. Moreover, a major aspect to consider is that ageing processes differ among species and direct inferences are rarely possible. This project aimed to compare age-induced changes in skin properties by studying two Wistar rat groups of different ages - young adult rats $(\mathrm{n}=7,20-24$ week-old) and old adult rats $(\mathrm{n}=5,48-72$ week-old). Non-invasive measuring approaches involving transepidermal water loss (TEWL), superficial hydration (MoistureMeter), and biomechanics (Reviscometer, and Cutometer by MPA 80) were taken in the animal dorsum (neck, bottom) over a period of five days, allowing statistical comparisons between groups. Results revealed no significant differences for TEWL, firmness or viscoelasticity between the two groups. However, a significant hydration decrease, of nearly $40 \%$, was noted in the old adult rats group. These results, although preliminary, if translatable to humans could be useful to address age-related changes in processes such as healing, or patch dressing efficacy/safety where hydration is a critical determinant. Their potential use for the prediction of efficacy and or safety of topically applied products for the elderly as compared to young adults may warrant further investigation..
\end{abstract}

Keywords: Wistar rat; TEWL; ageing; hydration; biomechanics.

\begin{abstract}
Resumo
Os modelos animais têm sido úteis para estudar mecanismos específicos que afetam a pele humana. É o caso do envelhecimento e das alterações micromecânicas que determinam o enrugamento (a formação de rugas) nos ratinhos irradiados com UV. Estes modelos permitiram perceber que o envelhecimento envolve muitas respostas mecânicas peculiares que não podem ser explicadas pela deformação homogénea da pele. No entanto, a diferença entre o tempo de vida destas espécies afeta também os processos e este é um aspeto principal a ter em conta. Este projeto é direcionado à comparação das propriedades cutâneas de dois grupos de ratos Wistar com diferentes idades - ratos jovens-adultos $(\mathrm{n}=7,20-24$ semanas) e adultos-velhos $(\mathrm{n}=5$, 48-72 semanas). Medições não-invasivas de perda transepidérmica de água (PTEA), hidratação superficial (MoistureMeter) e biomecânica (Reviscometer e Cutometer por MPA80) foram realizadas nas zonas dorsais (pescoço, dorso-posterior) do animal durante 5 dias, permitindo comparações estatísticas entre grupos. Os resultados não revelaram diferenças significativas para a PTEA, firmeza ou viscoelasticidade entre os dois grupos. Contudo, foi notada uma diminuição significativa, próxima de $40 \%$, da hidratação da pele no grupo dos ratos adultos-velhos. Estes resultados, apesar de preliminares, se fizermos a translação para os seres humanos poderiam ser úteis para avaliar mudanças relacionadas à idade em processos como a recuperação cutânea, ou eficácia / segurança de pensos, onde a hidratação é um factor determinante. A sua potencial utilização para a predição da eficácia e/ou segurança dos produtos de aplicação tópica para idosos em comparação aos adultos merecem ser exploradas.
\end{abstract}

Palavras-chave: rato Wistar; PTEA; envelhecimento; hidratação; biomecânica. 


\section{Introduction}

Ageing is a complex process that affects all species. It has been extensively studied and geriatrics is currently a target for research ${ }^{[1,2]}$. With regard to humans, it is clear that race/ethnicity, the intrinsic variations of different anatomical regions and the neuro-hormonal control are main determinants ${ }^{[3]}$ and the dermis is perceived to be the main target. Critical features are atrophy of the dermis due to loss of collagen, the degeneration in the elastic fibre network, and the loss of hydration ${ }^{[4]}$. Extrinsic factors, mainly environmental, also play an important role. It is estimated that $90 \%$ of the visible skin ageing process, specially in Caucasians, is due to the effects of ultraviolet (UV) radiation from sunlight ${ }^{[2,3,5-7]}$.

A relevant part of the knowledge accumulated derives from studies using animal models including rats ${ }^{[8]}$ and mice ${ }^{[9,10]}$ but the rats' skin ageing process has not been specifically approached. Some studies using Fischer 344 rats suggested a direct relationship between caloric restriction and the delay or prevention of histological alteration accompanying skin ageing ${ }^{[8]}$. Another study using CBA mice, revealed skin morphological alterations connected with growth ${ }^{[10]}$. Hairless SKH-1 rats were suggested to be convenient models for the study of photoageing ${ }^{[9]}$.

While proposing that using the in vivo rat skin model could be of value for the prediction of drug / environmental dermal safety effects associated to age in humans, the present study characterises the functional behavior of Wistar rats' cutaneous skin in different age groups by noninvasive biometric methodologies. It aims to identify potential differences between young and older adult rats' skin and the potential for any conclusions to be transferred to human skin.

\section{Materials and Methods}

Two groups of Wistar rats aged 21-24 weeks weighing $379 \pm 30 \mathrm{~g}$ (young-adult rats (AR); $\mathrm{n}=7$ ), and 48-72 weeks rats weighing $520 \pm 60 \mathrm{~g}$ (old-adult (OR); $\mathrm{n}=5$ ), were maintained under controlled temperature and humidity $\left(22 \pm 2{ }^{\circ} \mathrm{C} ; 40-50 \%\right)$, with a 12-hours light/dark cycle and fed with rat chow and water ad libitum. Animal experimentation was conducted in accordance with the relevant Community and National rules on animal protection for experimental and other scientific purposes. The animals were sedated with inhaled ethyl ether $(7 \mathrm{ml}$ embedded in the

\section{Introdução}

O envelhecimento é um processo complexo que afeta todas as espécies, tem sido extensivamente estudado e atualmente é alvo de investigação na área de geriatria ${ }^{[1,2]}$. No que diz respeito aos seres humanos, é claro que a raça/etnia, as variações intrínsecas das diferentes regiões anatómicas e as alterações neuro-hormonais são as principais determinantes ${ }^{[3]} \mathrm{e}$ a derme é vista como o alvo principal. As principais características são atrofia da derme, devido à perda de colagénio, a degeneração da rede de fibras elásticas, e a perda de hidrataçã ${ }^{[4]}$. Os fatores extrínsecos, principalmente os ambientais, também desempenham um papel importante. Estima-se que $90 \%$ do processo de envelhecimento visível da pele, especialmente em caucausianos, é devido aos efeitos da radiação ultravioleta (UV) do sol ${ }^{[2,3,5-7]}$.

Boa parte do conhecimento acumulado deriva de estudos utilizando modelos animais, incluindo ratos ${ }^{[8]}$ e ratinhos ${ }^{[9,10]}$, mas o processo de envelhecimento da pele do rato não foi especificamente abordado. Há estudos em ratos Fischer 344 que apontam para uma relação direta entre a restrição calórica e o atraso ou prevenção de alterações histológicas que acompanham o envelhecimento cutâneo ${ }^{[8]}$. Outro estudo em "ratinhos" CBA revelou alterações morfológicas cutâneas relacionadas com o envelhecimento ${ }^{[10]}$. Foi também reconhecido que "ratinhos" SKH-1 sem pêlo são modelos convenientes para o estudo do fotoenvelhecimento ${ }^{[9]}$.

Propondo que o uso de um modelo in vivo de pele de rato, poderia ser de grande valor para a previsão de efeitos de droga/ambiental - na segurança dérmica associada à idade em humanos, o presente estudo caracteriza o comportamento funcional cutâneo da pele de ratos Wistar em diferentes faixas etárias através de metodologias biométricas não invasivas, com o objetivo de identificar possíveis diferenças entre pele de ratos adultos jovens e velhos, e seu potencial de translação para a pele humana.

\section{Material e Métodos}

Dois grupos de ratos Wistar com idades de 21-24 semanas com média de peso $379 \pm 30 \mathrm{~g}$ (ratos adultos (RA); $n=7)$, e ratos de 48-72 semanas com média de peso $520 \pm 60 \mathrm{~g}$ (ratos velhos (RV); $\mathrm{n}=5$ ), os animais foram mantidos em condições de temperatura e humidade controlada $\left(22 \pm 2^{\circ} \mathrm{C} ; 40-50 \%\right)$, com 12 horas de ciclo luz/escuro, com acesso a ração e água $a d$ libitum. A experimentação animal foi conduzida de acordo com as normas Comunitárias e Nacionais relativas à protecção dos animais utilizados para fins experimentais e outros fins científicos. Os animais 
patch) to avoid any additional stress. Two opposite dorsal areas $\left(2 \mathrm{~cm}^{2}\right.$, neck and bottom) were marked on the animal dorsum, after mechanical removal of the body hair (24 hours before starting the study). Measurements included transepidermal water loss (TEWL), obtained with Tewameter ${ }^{\circledR}$ TM300 (CK electronics, Germany) expressed in $\mathrm{g} / \mathrm{m}^{2} / \mathrm{h}$; superficial epidermal hydration, measured by the MoistureMeter ${ }^{\circledR}$ SC (Delphin, Kuopio, Finland) expressed in arbitrary units (AU); and biomechanical behavior obtained by the Cutometer ${ }^{\circledR}$ MPA 80 system, equipped with an $8 \mathrm{~mm}$ diameter probe, and by the Reviscometer ${ }^{\circledR}$ RVM600 system, both from CourageKhazaka, Cologne, Germany. Measurements took place daily over a period of five days (D1-D5). The chosen cutometry descriptors were R0 or Uf (maximum distension of the first curve), $\mathrm{R} 2$ or $\mathrm{Ua} / \mathrm{Uf}$ (elasticity of the skin, including pulse stretching and recovery), R5 or Ua/Uf (total elasticity), R6 or Uv/Ue (or viscoelasticity ratio, the relationship between elastic and viscoelastic extension), and $\mathrm{R} 8$ or $\mathrm{Ua}$ (from the first curve), obtained through the suction pulse that characterizes this method ${ }^{\left[1,12^{2}\right]}$. For the reviscometer system we selected the RRTm (Resonance Running Time - mean value) measured at five angles $\left(0^{\circ}, 45^{\circ}\right.$, $90^{\circ}, 135^{\circ}$ and $180^{\circ}$ ) and anisotropy, obtained by dividing the ratio RRTmaximum/ RRT minimum ${ }^{[1]}$. These are expressed in arbitrary units (AU).

Statistics involved an Unpaired t test (GraphPad Prism 5.0) and a Friedman test (SPSS 17.0) for baseline comparison between the experimental sites. A 95\% confidence level was adopted.

\section{Results and Discussion}

The outcome of the comparison of the baseline values from D1-D5 is presented in Table 1.

As shown, from the $p$ values obtained, no differences were found in the functional status of the skin in all experimental sites during the experimental period. This similarity is essential in order to proceed with the comparative analysis.

Table 2 and Figures 1 to 5 summarize the skin biometrical descriptors obtained in both groups.

Transepidermal water loss (TEWL) is a frequentely used parameter, in both human and animal skin studies to describe epidermal "barrier", especially when evaluating the integrity of skin after trauma from foram previamente sedados com inalação de éter etílico ( $7 \mathrm{ml}$ em um algodão) para evitar qualquer stresse adicional. Duas áreas opostas $\left(2 \mathrm{~cm}^{2}\right.$, uma próxima do pescoço e outra próxima da cauda) foram selecionadas no dorso do animal após remoção mecânica dos pêlos (24 horas antes do inicio do estudo).

Os parâmetros avaliados incluíram a Perda Transepidérmica de Água (PTEA), através do Tewameter ${ }^{\circledR}$ TM300 (CK electronics, Germany), expressa em $\mathrm{g} / \mathrm{m}^{2} / \mathrm{h}$; a hidratação superficial epidérmica medida através do MoistureMeter ${ }^{\circledR}$ SC (Delphin, Kuopio, Finland), expressa em unidades arbitrárias (UA); e medida biomecânica através do Cutometer ${ }^{\circledR}$ sistema MPA80, equipado com uma sonda de $8 \mathrm{~mm}$ de diâmetro, e do Reviscometer ${ }^{\circledR}$ sistema RVM600, ambos da Courage-Khazaka, Cologne, Germany. As medições foram realizadas diariamente por um período de cinco dias (D1-D5). Na cutometria os descritores escolhidos para análise foramo R0 ou Uf (a distensão máxima da primeira curva), R2 ou Ua/Uf (a elasticidade total da pele, incluindo o pulso de distensão e de recuperação), R5 ou Ur/Ue (elasticidade total), R6 ou Uv/Ue (razão viscoelástica, a relação entre a extenção viscoelástica e elástica), e R8 ou Ua (primeira curva) obtidos através do pulso de sucção que caracteriza este método ${ }^{[11,12]}$. Já para o reviscometer, foi selecionado o RRTm (Resonance Running Time - valor médio) medido em cinco ângulos $\left(0,45,90,135\right.$ e $\left.180^{\circ}\right)$ e a Anisotropia, obtida pela razão entre o RRT máximo e o RRT mínimo ${ }^{[11]}$. Ambos expressos em unidades arbitrárias (UA).

O tratamento estatístico dos dados foi realizado através do Teste $t$ desemparelhado (GraphPad Prism 5.0) e o teste de Friedman (SPSS 17.0) foi utilizado para comparação dos valores basais entre os sítios experimentais. O nível de confiança adotado foi $95 \%$.

\section{Resultados e Discussão}

Os resultados da comparação dos valores basais do D1 ao D5 estão na Tabela1. Como demonstrado, a partir de valores obtidos de $p$, não foram encontradas diferenças significativas entre o estado funcional da pele em todos os sítios durante o período experimental. Esta semelhança é essencial para prosseguir com a análise comparativa.

A Tabela 2 e as Figuras 1 a 5 resumem os resultados obtidos relativos à caracterização biométrica da pele nos dois grupos animais.

A perda transepidérmica de água (PTEA) é uma variável muito utilizada, seja em modelos humanos ou animais, principalmente nos estudo que avaliam a integridade da pele após trauma de diferentes origens ${ }^{[13,15]}$, assim como 
different origins ${ }^{[13,15]}$ or to test the efficacy of therapeutical interventions ${ }^{[12,}{ }^{15-17]}$. TEWL results obtained in our study (Figure 1) revealed an insignificant ( $p=0.0643$ ) decrease of $\approx 18 \%$ for the old-adult (OR) when compared to the young-adult (AR) group. These values, when compared with baseline data from hairless rats (CD hrBi) (250$300 \mathrm{~g}){ }^{[18]}$, are similar to the ones obtained in this study with OR. avaliar a eficácia da aplicação terapêutica ${ }^{[12,15-17]}$. Os resultados de PTEA obtidos no nosso estudo (Figura 1) revelaram uma diminuição, estatisticamente não significativa $(\mathrm{p}=0.0643), \mathrm{de} \approx 18 \%$ nos animais velhos (RV) quando comparados ao grupo de animais adultos (RA). Estes valores quando comparados com os dados basais obtidos em estudos com ratos sem pêlo (CD hrBi) (250-300g) - ${ }^{[18]}$ são semelhantes aos dados obtidos neste estudo para os RV.

Table 1 - Comparison of baseline (D1) and between every other day (D1 - D5) across the sites for each experimental technique of biometric evaluations ( $\mathrm{p}$-value obtained by the Friedman test - SPSS).

Tabela 1 - Comparação dos valores basais (D1) e entre todos os outros dias (D1 - D5) entre todos os sitio experimentais para cada técnica de avaliação biométrica (valor p obtido através do teste de Friedman - SPSS).

\begin{tabular}{|c|c|c|c|c|}
\hline \multirow[b]{3}{*}{ Variables / Variáveis } & \multicolumn{4}{|c|}{ Rats/Ratos } \\
\hline & \multicolumn{2}{|c|}{ Old-Adult / Velhos } & \multicolumn{2}{|c|}{ Young A dults / Adultos } \\
\hline & D1 & $\begin{array}{l}\text { D1-D5 para todos os } \\
\text { sítios }\end{array}$ & D1 & $\begin{array}{l}\text { D1-D5 para todos os } \\
\text { sítios }\end{array}$ \\
\hline TEWL/PTEA $\left(\mathrm{g} / \mathrm{m}^{2} / \mathrm{h}\right)$ & 0.564 & 0.350 & 0.083 & 0.199 \\
\hline Cutometer (R5) (AU/UA) & 0.655 & 0.188 & 0.059 & 0.061 \\
\hline RRTm (AU/UA) & 0.655 & 0.105 & 1.00 & 0.683 \\
\hline Anisotropy/Anisotropia (AU/UA) & 0.655 & 0.09 & 0.257 & 0.582 \\
\hline $\begin{array}{l}\text { Superficial Hydration/ Hidratação } \\
\text { superficial (UA) }\end{array}$ & 0.655 & 0.107 & 0.591 & 0.231 \\
\hline
\end{tabular}

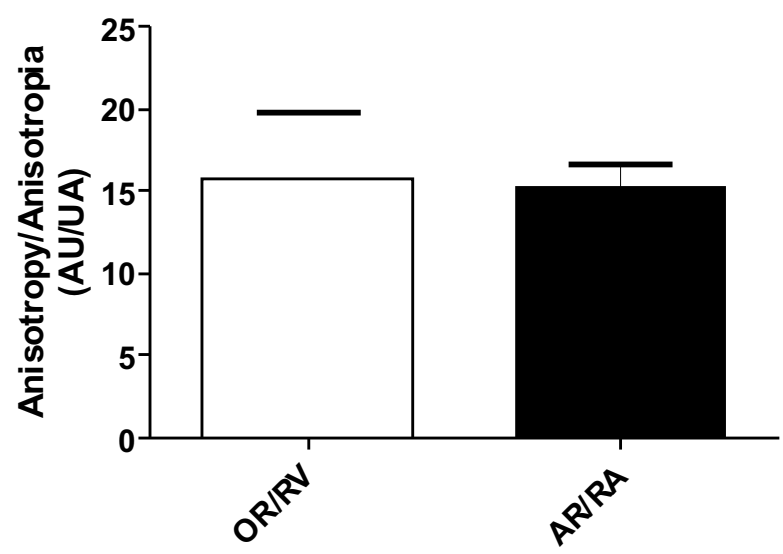

Figure 3 - Anisotropy in Wistar rats: old - adult (OR/RV 48-72 weeks of age) and young-adult (AR/RA - 48-72 weeks of age) ones ( $\mathrm{n}=5$ and $\mathrm{n}=7$ for each group respectively). The data bars represent means \pm S.E.M. of measurements; AU- arbitrary units.

Figura 3 - Anisotropia em ratos Wistar: animais velhos (OR/RV - 48-75 semanas de idade) e adultos (AR/RA - 4875 semanas de idade) ( $\mathrm{n}=5$ e $\mathrm{n}=7$ para cada grupo respectivamente). As barras dos dados representam a média \pm dpm das medições; UA - unidades arbitrárias. 
Table 2 - Quantitative data obtained in each non-invasive measurement: transepidermal water loss (TEWL), superficial epidermal hydration, and the biomechanics (RRT (resonance running time) by RRTm (resonance running time - mean value) and anisotropy; and cutometry (descriptors R0, R2, R5, R6, e R8).

Tabela 2 - Dados quantitativos obtidos em cada um dos parametros avaliados: perda transepidérmica de água (PTEA), hidratação superficial epidérmica, e biomecânicos (RRT (resonance running time) por RRTm (resonance running time - valor médio) e anisotropia; e Cutometria (descritores R0, R2, R5, R6, e R8).

\begin{tabular}{|c|c|c|}
\hline \multirow[b]{2}{*}{ Variables / Variáveis } & \multicolumn{2}{|c|}{ Rats/Ratos } \\
\hline & $\begin{array}{c}\text { Old Adult / Velhos } \\
\text { mean/méd } \pm \text { sem/dpm }\end{array}$ & $\begin{array}{l}\text { Young Adults / Adultos } \\
\text { mean/méd } \pm \text { sem/dpm }\end{array}$ \\
\hline TEWL/PTEA $\left(\mathrm{g} / \mathrm{m}^{2} / \mathrm{h}\right)$ & $8.585 \pm 0.19$ & $10.45 \pm 0.85$ \\
\hline RRTm (AU/UA) & $912.3 \pm 213.3$ & $1080 \pm 83.26$ \\
\hline Anisotropy/Anisotropia (AU/UA) & $15.75 \pm 3.96$ & $15.28 \pm 1.33$ \\
\hline R0 (Uf) (mm) & $1.44 \pm 0.42$ & $0.911 \pm 0.18$ \\
\hline R2 (Ua/Uf) (AU/UA) & $0.99 \pm 0.29$ & $1.40 \pm 0.12$ \\
\hline R5 (Ur/Ue) (AU/UA) & $0.08 \pm 0.03$ & $0.07 \pm 0.04$ \\
\hline R6 (Uv/Ue) (UA) & $0.11 \pm 0.02$ & $0.06 \pm 0.04$ \\
\hline $\mathrm{R} 8$ (Ua) (mm) & $0.24 \pm 0.109$ & $0.06 \pm 0.0264$ \\
\hline $\begin{array}{l}\text { Superficial Hydration/ Hidratação } \\
\text { superficial (UA) }\end{array}$ & $23.47 \pm 3.79$ & $41.26 \pm 3.67$ \\
\hline
\end{tabular}

RRTm and anisotropy did not reveal significant differences between both age groups $(\mathrm{p}=0.4845$ and $\mathrm{p}$ $=0.9134$ respectively) (Figures 2 and 3 ). These unchanged parameters suggest the absence of changes in skin elasticity or viscoelasticity during the animal ageing process, although a decrease on RRTm measurements $(15 \%)$ is observed in old-adult rats (OR) when compared with adults (AR). A study with nude mice (Balb/c, 4 weeks old) ${ }^{[19]}$ showed different RRTm baseline results $(463.8 \pm 28.5)$, but the skin of these animals was pretreated with a Phosphate Buffer Solution PBS, as different skin properties are probably admissible for these two strains.
A RRTm e anisotropia, também não mostraram diferenças estatisticamente significativas entre ambos os grupos $(\mathrm{p}=0.4845 \mathrm{e} \mathrm{p}=0.9134$ respetivamente $)$ (Figuras 2 e 3). Estes parâmetros se mantêm-se inalterados e sugerem a ausência de mudanças na elasticidade da pele ou viscoelasticidade durante o processo de envelhecimento animal, mesmo tendo uma redução nos valores obtidos da RRTm (15\%) nos animais velhos (RV) quando comparados com os valores dos animais adultos (RA). Um estudo com "ratinhos" nude (Balb/C, 4 semanas de idade) ${ }^{[19]}$ mostrou resultados basais diferentes para RRTm (463.8 \pm 28.5$)$, porém estes animais foram tratados com solução de tampão fosfato (PBS), como apresentam características diferentes admissíveis para as duas linhagens. 

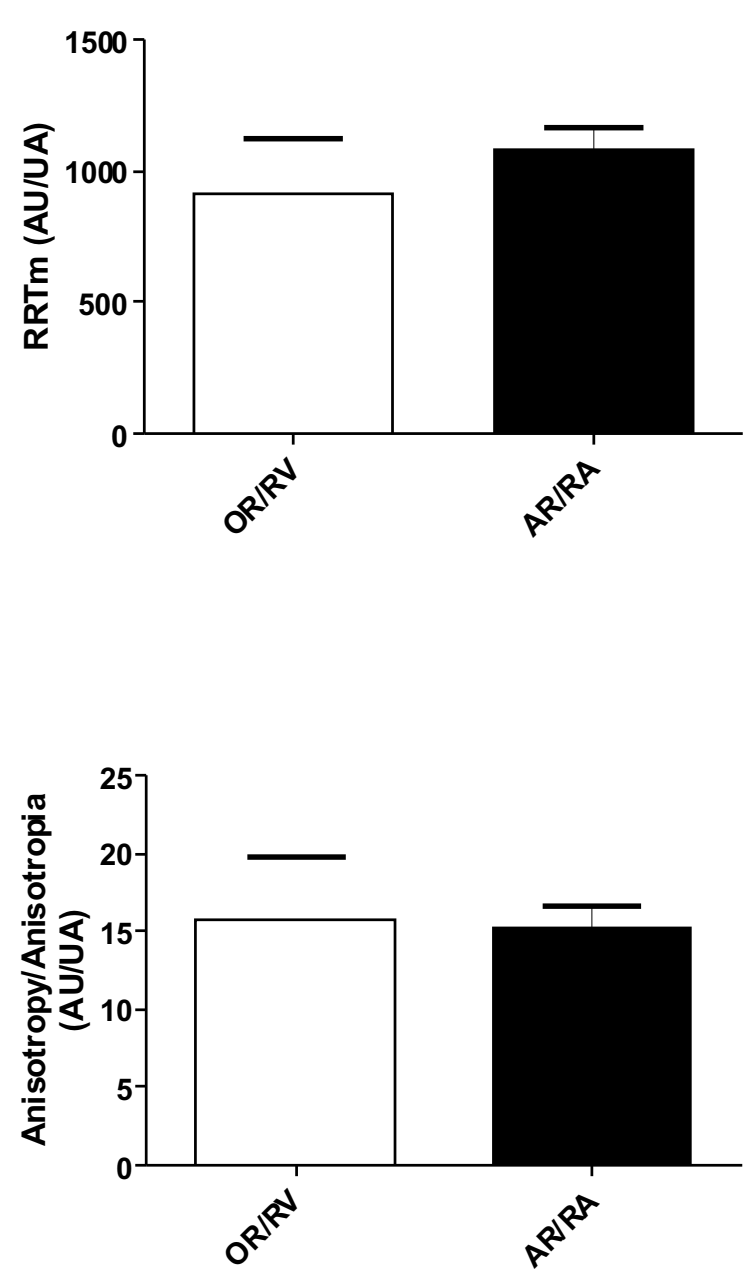

Other biomechanical descriptors revealed no significant differences between groups (Figure 4) (R0, $\mathrm{p}=0.2876, \mathrm{R} 2, \mathrm{p}=0.2319 ; \mathrm{R} 5, \mathrm{p}=0.1478 ; \mathrm{R} 6, \mathrm{p}=$ 0.3055 , and $R 8, p=0.3148$ ). However, studies in the literature indicate that the value of descriptor $\mathrm{Uv} / \mathrm{Ue}$ (or viscoelasticity index or R6) increases with the ageing process in human skin ${ }^{[12]}$. Our study also revealed an increased trend on this indicator, $\approx 43 \%$ old-adult rats (OR) compared to young-adult (AR) ones, but it is not statistically significant. When our results are compared with baseline results obtained in other studies using rat strains such as Sprague-Dawley (hind limb skin) ${ }^{[20]}$ or hairless rats (WBN / ILA-HT) (dorsal skin $)^{[21]}$, no similarities are found $(\mathrm{R} 0=0058 \pm$ 0016 and $\mathrm{R} 0=0206 \pm 0025$, respectively) probably because the skin and/or the sites of these animals have different characteristics.
Figure 2 - Resonance running time - mean value (RRTm) in Wistar rats: old-adult (OR/RV - 48-72 weeks of age) and young-adult (AR/RA - 48-72 weeks of age) ones ( $n=5$ and $\mathrm{n}=7$ for each group respectively). The data bars represent means \pm S.E.M. of measurements; $A U$ - arbitrary units.

Figura 2 - Resonance running time - valor médio (RRTm) em ratos Wistar: animais velhos (OR/RV - 48-75 semanas de idade) e adultos (AR/RA - 48-75 semanas de idade) $(\mathrm{n}=5$ e $n=7$ para cada grupo respectivamente). As barras dos dados representam a média \pm dpm das medições; UA unidades arbitrárias.

Figure 3 - Anisotropy in Wistar rats: old - adult (OR/RV 48-72 weeks of age) and young-adult (AR/RA - 48-72 weeks of age) ones ( $\mathrm{n}=5$ and $\mathrm{n}=7$ for each group respectively). The data bars represent means \pm S.E.M. of measurements; $\mathrm{AU}$ - arbitrary units.

Figura 3 - Anisotropia em ratos Wistar: animais velhos (OR/RV - 48-75 semanas de idade) e adultos (AR/RA - 4875 semanas de idade) ( $\mathrm{n}=5$ e $\mathrm{n}=7$ para cada grupo respectivamente). As barras dos dados representam a média \pm dpm das medições; UA - unidades arbitrárias.

Os outros descritivos biomecánicos revelaram diferenças não significativas entre os dois grupos (Figura 4) $(\mathrm{R} 0, \mathrm{p}=0.2876 ; \mathrm{R} 2, \mathrm{p}=0.2319$; $\mathrm{R} 5, \mathrm{p}=0.1478$; $\mathrm{R} 6, \mathrm{p}=0.3055$ e $\mathrm{R} 8, \mathrm{p}=0.3148$ ). Contudo a literatura indica que o valor do descritor Uv/Ue (ou razão viscoelástica ou R6) aumenta com o processo de envelhecimento da pele humana ${ }^{[12]}$. O nosso trabalho corrobora estes dados pois este indicador também aumentou, $\approx 43 \%$ nos ratos velhos $(\mathrm{RV})$ em relação aos adultos (RA), mesmo não sendo estatisticamente significativo. Já quando os nossos resultados são comparados com os resultados basais obtidos em outros estudos com linhagens de ratos como os SpragueDawley (pele da região inferior da pata) ${ }^{[20]}$ ou os ratos sem pêlo (WBN/ILA-HT) (pele do dorso) ${ }^{[21]}$ não se observam semelhanças $(\mathrm{R} 0=0.058 \pm 0.016$ e $\mathrm{R} 0=$ $0.206 \pm 0.025$, respectivamente) talvez porque a pele destes animais tenha características diferentes. 


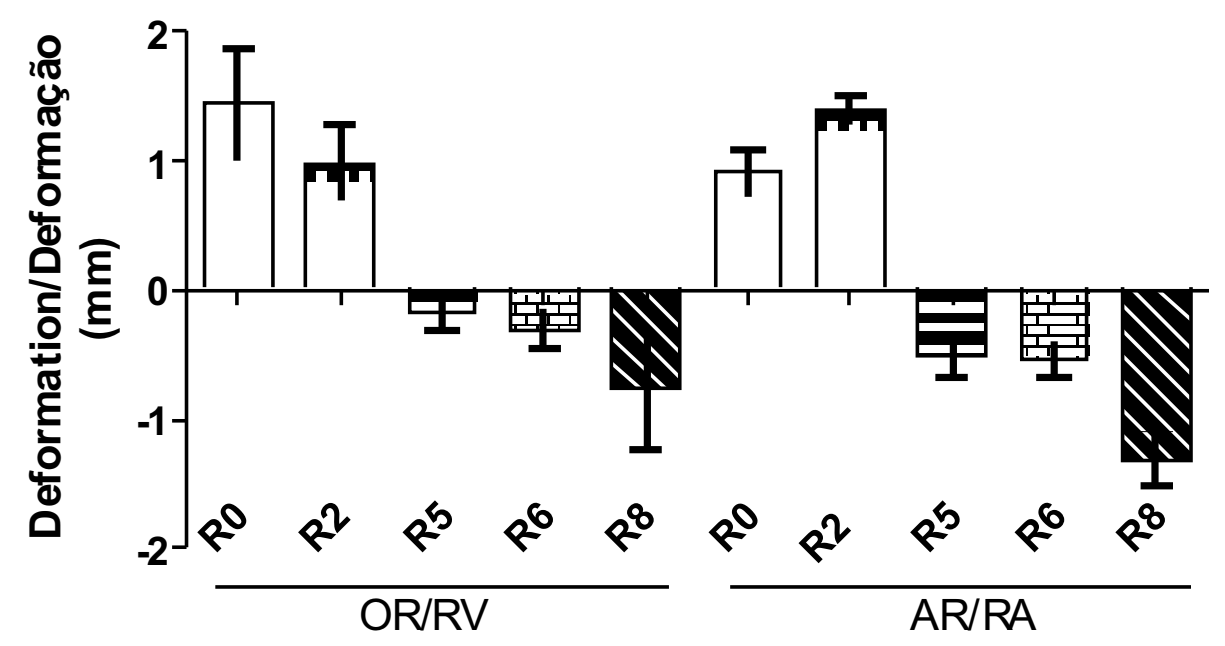

Figure 4 - Cutometry (descriptors R0, R2, R5, R6 and R8) in Wistar rats: old (OR/RV - 4872 weeks of age) and young -adult (AR/RA - 48-72 weeks of age) ones ( $n=5$ and $n=7$ for each group respectively). The data bars represent means \pm S.E.M. of measurements; $\mathrm{mm}$ millimeter.

Figura 4 - Cutometria (descritores R0, R2, R5, R6 and R8)em ratos Wistar: animais velhos (OR/RV - 48-75 semanas de idade) e adultos (AR/RA - 48-75 semanas de idade) (n=5 e $n=7$ para cada grupo respectivamente). As barras dos dados representam a média \pm dpm das medições; mm - milimetro.

Superficial epidermal hydration was the sole parameter showing a statistically significant difference between both age groups $(\mathrm{p}=0.0098)$ with a $\approx 43 \%$ reduction in older rats $(\mathrm{OR})$ (Figure 5 ). These values are similar to previously published results obtained in the ear of Balb/c mice ${ }^{[22]}$, and are especially relevant in the processes such as healing or patch dressing efficacy, where hydration is a critical determinant. The fact that the ageing process in rats has similarly affected skin hydration, and the fact that this change could be detected with our noninvasive technique, suggest that this may be of value in predicting, with human translational value, potential differential effects of topically applied products in aged vs young adults, in that which concerns safety or efficacy aspects.
A hidratação superficial epidérmica foi o único parâmetro que obteve diferença significativa entre os grupos $(\mathrm{p}=0.0098)$ com uma redução de $\approx 43 \%$ nos animais velhos (RV) (Figura 5). Estes valores são semelhantes a valores previamente publicados obtidos na pele da orelha de "ratinhos" Balb/c ${ }^{[22]}$, e são especialmente relevantes nos processos, tais como a recuperação cutânea, ou a eficácia de patch curativo, onde a hidratação é um determinante crítico. $O$ facto de o processo de envelhecimento em ratos ter tido a hidratação da pele igualmente afectada e o facto de que essa alteração pode ser detectada com a nossa técnica não invasiva, sugerem que esta técnica pode ser de grande utilidade para prever a translação dos valores para o humano, potenciais efeitos diferenciais dos produtos aplicados topicamente em idosos vs jovens, no que diz respeito à aspectos de segurança ou eficácia. 


\section{Conclusion}

In this preliminary study we have been able to show that the in vivo rat skin model has been appropriate in identifying some age-related changes in skin physiology, expressed by reduced hydration in the aged animals as compared to the adults. A trend for decreased RRTm was also identified. We acknowledge that results may have been influenced by the short dimension of the animal groups and the variability of some descriptors (biomechanics, for instance). However, these results indicate a potential for this model to be an interesting one for skin studies, specially adequate to some address and predict the potential skin reactivity in terms of efficacy and safety to topically applied components like drugs in the elderly as compared to young adults. This may be of help in cases where the very elderly are to be included in clinical trials with the inherent difficulties associated with studying such age groups.

\section{Conflict of Interest}

The authors declare that there is no financial or personal relationship that can be understood as representing a potential conflict of interest.

\section{Conclusão}

Neste estudo preliminar, o modelo in vivo em pele de ratos demonstrou ser adequado para identificar alterações relacionadas com a fisiologia do envelhecimento da pele, expressas por redução da hidratação nos animais velhos, em comparação com os adultos. Foi identificada também tendência de diminuição da RRTm. Como limitação, reconhece-se que os resultados podem ter sido influenciados pela dimensão pequena dos grupos de animais e pela variabilidade de alguns descritores (biomecánicos, por exemplo). No entando, os resultados indicam o potencial deste modelo para estudos de pele, especialmente na predição da reactividade potencial da pele (em termos de eficácia e segurança) a formulações de uso tópico, em idosos comparativamente a jovens. $\mathrm{O}$ modelo pode ser útil, assim, em caso de estudos em idosos, cuja inclusão em ensaios clínicos apresenta dificuldades inerentes.

\section{Conflito de Interesses}

Os autores declaram não existir qualquer relação pessoal ou financeira que possa ser entendida como representando um potencial conflito de interesses.

\section{References / Referências}

[1].Fisher GJ, Kang S, Varani J, Bata-Csorgo Z, Wan Y, Datta S, Voorhees JJ. Mechanisms of photoaging and chronological skin aging. Arch Dermatol2002 Nov;138(11):1462-70.

[2].Hwang KA, Yi BR, Choi KC. Molecular mechanisms and in vivo mouse models of skin aging associated with dermal matrix alterations. Lab Anim Res2011 Mar;27(1):1-8.

[3].Farage MA, Miller KW, Elsner P, Maibach HI. Intrinsic and extrinsic factors in skin ageing: a review. Int J Cosmet Sci2008 Apr;30(2):87-95.

[4].Uitto J. The role of elastin and collagen in cutaneous aging: intrinsic aging versus photoexposure. J Drugs Dermatol2008 Feb;7(2 Suppl):s12-6.

[5].Giacomoni PU, Rein G. Factors of skin ageing $\mathrm{sh}$ a e com mo $\mathrm{mech}$ a $\mathrm{n}$ is $\mathrm{ms}$. Biogerontology2001;2(4):219-29.

[6].Kligman LH, Gebre M, Alper R, Kefalides NA. Collagen metabolism in ultraviolet irradiated hairless mouse skin and its correlation to histochemical observations. J Invest Dermatol1989 Aug;93(2):210-4.

[7].Sudel KM, Venzke K, Mielke H, Breitenbach U, Mundt C, Jaspers S, Koop U, Sauermann K, Knussman-Hartig E, Moll I, Gercken G, Young AR, Stab F, Wenck H, Gallinat S. Novel aspects of intrinsic and extrinsic aging of human skin: beneficial effects of soy extract. Photochem Photobiol2005 May-Jun;81(3):581-7.

[8].Thomas JR. Effects of age and diet on rat skin histology. Laryngoscope2005 Mar;115(3):405-11.
[9].Moloney SJ, Edmonds SH, Giddens LD, Learn DB. The hairless mouse model of photoaging: evaluation of the relationship between dermal elastin, collagen, skin thickness and wrinkles. Photochem Photobiol1992 Oct;56(4):505-11.

[10]. Bhattacharyya TK, Thomas JR. Histomorphologic changes in aging skin: observations in the CBA mouse model. Arch Facial Plast Surg2004 Jan-Feb;6(1):21-5.

[11].Tavares L, Palma L, Almeida A, Bujan MJ, Rodrigues LM. Development of an in vivo method to better understand the obese skin. Biomedical and Biopharmaceutical Research2012;9(1):87-93.

[12].Serup J, Jemec GBE, Grove GL. Handbook of Non-Invasive Methods and the Skin,Second Edition [Jorgen Serup, Gregor B. E. Jemec, Gary L. Grove. 2nd ed. London: Taylor \& Francis Group, LLC; 2006.

[13].Babu RJ, Chatterjee A, Singh M. Assessment of skin irritation and molecular responses in rat skin exposed to nonane, dodecane and tetradecane. Toxicology Letters2004;153(2):255-66.

[14].Graham JS, Schomacker KT, Glatter RD, Briscoe CM, Braue EH, Jr., Squibb KS Bioengineering methods employed in the study of wound healing of sulphur mustard burns. Skin Res Technol2002 Feb;8(1):57-69.

[15].Pereira MM. Estudo in vivo do impácto biológico de diferentes materiais de penso sobre a integridade cutânea. Lisboa: Universidade de Lisboa; 2009.

[16].Pereira MM, Rodrigues LM. Efeito da Oclusão com um apósito de ácido hiaulurónico sobre a recuperação da barreira cutânea seguido por evaporimetria e sonografia de alta frequência. Rev Lusófona de Ciências e Tecnologias da Saúde2008;6(1):77-85.

[17].Pereira MM, Saraiva J, Rodrigues LM. The inpact of Occlusion in vivo Skin Inegrity Recovery. Biomedical and Biopharmaceutical Research2011;8(2):313-19.

[18].Kanikkannan N, Locke BR, Singh M. Effect of jet fuels on the skin morphology and irritation in hairless rats. Toxicology2002;175(13):35-47.

[19].Yamamoto T, Nishioka K. Animal model of sclerotic skin. VI: Evaluation of bleomycin-induced skin sclerosis in nude mice. Archives of Dermatological Research2004;295(10):453-6.

[20].Tsukahara K, Takema Y, Moriwaki S, Fujimura $\mathrm{T}$, Imayama S, Imokawa G. Carbon dioxide laser treatment promotes repair of the three-dimensional network of elastic fibres in rat skin. $\mathrm{Br} \mathrm{J}$ Dermatol2001 Mar;144(3):452-8.

[21].Fujimura T, Moriwaki S, Imokawa G, Takema Y. Crucial role of fibroblast integrins alpha2 and beta1 in maintaining the structural and mechanical properties of the skin. J Dermatol Sci2007 Jan;45(1):45-53.

[22].Yeom M, Kim SH, Lee B, Han JJ, Chung GH, Choi HD, Lee H, Hahm DH. Oral administration of glucosylceramide ameliorates inflammatory dryskin condition in chronic oxazolone-induced irritant contact dermatitis in the mouse ear. J Dermatol Sci2012 Aug;67(2):101-10. 